\title{
TEACHER'S TECHNOLOGY INTEGRATION ELT BASED ON SAMR MODEL IN WRITING SKILL
}

\author{
Dani Fathurohman', Andi Dian Rahmawan² \\ ${ }^{1,2}$ Universitas PGRI Yogyakarta \\ Corresponding Author: Danifathurohman999@gmail.com
}

\begin{abstract}
:
This study is aimed to know the technology categories integrated by the teacher and classify the teacher's technology integration level. Descriptive qualitative is used to describe the result of this study. The data is collected through interview and observation at SMA N 1 SENTOLO. It is focused on the teaching of writing. the subject of this research were 2 teacher. The data were transformed into descriptive text and interviewed transcripts. The data analysis used reduction data, the data display, and conclusion drawing or verification. The data validation used triangulation of technique of collecting data and triangulation of source of data. The source of data taken from interview. Based on the result of finding and discussion, it is found that the teacher integrated more than four technology categories which are word processing, spreadsheet software, organizing and brainstorm, multimedia, and web resources. The teacher integrated those technologies in teaching listening, reading and writing skill. While the activities is analysed based on SAMR model to know the teacher's technology integration. The result shows that the teacher is on the augmentation level in teaching writing skill, which the teacher uses word processing with additional functions like spell check, cut, and paste the documents. Therefore, the teacher is classified on passing the substitution level, because the teacher is on the augmentation level, which integrates technology as a direct tool substitute, with functional improvement.
\end{abstract}

Keywords:

Technology

Integration,SAMR,

ELT (English

Language Teaching)

\section{INTRODUCTION}

The Minister of Education and Culture of Republic of Indonesia has instructed schools to carry out online learning since 17 March 2020 for COVID-19 affected areas (Mendikbud, 2020b). Soon after that, the Minister of Education and Culture of Republic of Indonesia has ordered all education units to run online learning from 24 March 2020 due to the increasing spread of COVID-19 and maintaining the health of students, teachers, and all educational staffs (Mendikbud, 2020a). These policies lead students to learn from home and teachers to work from home, too. It fully replaces face-to-face learning in classroom setting into online learning which possibly lasts till the end of semester due to the COVID-19 pandemic. It becomes a new challenge for both students 
and teachers to run online learning. According to Cao et al.(2020), these actions certainly give impact on education, particularly students' growth.

With the increasing number of technology integration practices in the classrooms, studies on the area also gain more attention. From the studies, we learned that technology integration offers benefits for English language teaching and learning (ELTL). Hennesy (2005, as cited in Ahmadi and Guilan, 2018) find out that the use of technology in the classroom increases student motivation to learn while Baytak, Tarman, and Ayas (2011) as cited in Ahmadi and Guilan, (2018) find that technology integrations encourages more active learning for the student, makes learning enjoyable and helps the students to learn more. Supporting Baytak, Tarman, and Ayas finding, Ozerol (2009), as cited in Riasati, Allahyar, \& Tan, (2012) find that the teachers in his research agreed that technology lowering learning anxiety level and provides a less stressful environment than classroom learning. According to Richard (2015) and Riasati, Allahyar, \& Tan (2012), the use of technology also changed the methods from teacher-centered to learner-centered ones and provides new roles for teachers from a transmitter of knowledge to a facilitator who supports and guides student learning.

In the observation researcher found some problem. First,Teachers who cannot use technology competently will waste a lot of time with the technical problems. Second,The use of technology in the classroom, such as using the internet could bring excitement amongst students but they might get distracted to see other websites and not do the tasks the teacher has assigned for them. Third,Poor connectivity of the internet and the lack of technology facilities (such as LCD, Computer, etc) may cause problems for the teaching and learning process. In line with that finding, Romano (2003) as cited in Riasati, Allahyar, \& Tan (2012) said that technology does not improve learning unless teachers are empowered to adopt technology as an educational tool. Also, Beggs (2000), Balanskat et al. (2006) as cited in Riasati, Allahyar, \& Tan, (2012) stated that teachers' lack of confidence, fear of failure, or lack of technology knowledge made them feel anxious to integrating technology in the classroom.

Definition of Writing,Nunan (2003:88) states that writing is an intelectual activity or finding the ideas and thinking about the way to express and arrange them into a statement and paragraph that is clear to be understood by the people. It indicates that the writers are demanded to show the thoughts and organize them into a good composition. In addition, writing presents the writer's concept in understanding an issue which is shown to the public. It requires the integration of idea systematically written. Writing is considered as an active creation of text involves on the one hand lower-order transcription skills such as handwriting,punctuation and apelling, and on the other hand,higher-order self regulated thinking process such as planning,sequencing and expressing the content(berninger at al,2002). It requires the writer to express the content of writing into a good composition by considering the aspects of writing to be understod by the readers.

According to white and arndt (1991) in hammand (2013:1), writing is a thinking process which demands intellectual effort and it involves generating ideas,planning,goal selting,monitoring,evaluating what is going to be written as well what has been written and using language for expressingg exact meanings. It means that writing consist of somr stages that should be done by the writer in coveying the mesage of writing. Based on explanation, it can be concluded that writing is an effort to express the writer's thinking,feelin, or ideas in written form by considering writing aspects and writing stages to be clear understood by the readers. There are some principle regarding to put sentence 
by sentence and paragraph by paragraph, and thet are not so easy to comprehend (Saadat\&Dastgerdi2014) in (Barnaba\& Rahwawan,2019)

The level of SAMR Model has connection within Bloom's Digital Taxonomy, which is developed by Benjamin Bloom. Benjamin Bloom's Taxonomy of Educational Objectives can help teachers classify their objectives to determine the various challenges of students ${ }^{\text {ee }}$ learning in using technology which based on targets a higher-order cognitive skill level. There are six levels from the highest level to the lowest level as follows creating, evaluating, analysing, applying, understanding, and remembering. Here's how technology fits into the domains of Bloom's taxonomy.

A. The knowledge level or remembering. In technology use, tasks at the remembering level might include conducting simple online searches, making an acrostic or bulleted list, writing facts, or listing main events. This level includes on the substitution level of SAMR model as the lowest level.

B. The comprehension level or understanding. One step up from remembering come understanding. At this level, students explain, compare, discuss, interpret, restate, summarize, sort, and infer. Technology tasks that demonstrate understanding include conducting an advanced Boolean search, drawing picture or event, making flow chart of events in a story or history lesson, outlining or summarizing a text, sorting into a Venn diagram, journaling, or commenting on a blog. This level includes on the augmentation level of SAMR model.

C. The application level or applying. Tasks in the application level require students to apply what they understand to new situations. Applying refers to solving, using, illustrating, constructing, classifying, and examining. Students working at this level may be solving problem on a math site, taking or selecting pictures to illustrate a concept, editing written work, developing a plan, uploading documents to a wiki, interviewing with a digital recorder, making a pattern, building a presentation, or contacting an expert. It is including on augmentation and modification level of SAMR model.

D. The analysis level or analysing. With analysis, students begin to use critical thinking skills to understand concepts. Verbs that fit into the analysis level include compare/contrast, investigate, organize, plan, structure, link, and deconstruct. Students working at this level with technology tools may be writing and advertisement, creating a Venn diagram on a subject of study, researching a concept, building a concept map, developing a questionnaire, writing a blog, conducting a survey, or developing spread sheet. This level includes on the modification of SAMR model.

E. The evaluation level or evaluating. In evaluation, students use higher-level thinking skills to appraise ideas or materials based on criteria. Students might decide, choose, justify, debate, recommend, rate, or prioritize at this level. In the past, when students conducted research in library books, the materials had already been vetted, so while the information might not be current, its source could be trusted. With online research, however students must appraise the credibility of source before using it. Other technology-based tasks also require evaluation skills, such as writing a persuasive argument, engaging in an online discussion group, narrowing a search to target results, or critiquing books on a book review site. It includes modification and redefinition level of SAMR model.

F. The synthesis level or creating. Creating, the highest level on Bloom 'e staxonomy, describes what happens when students use their knowledge to create or produce 
something new. When students engage in creating, they are active learners who make choices about how demonstrate what they know. At this level, students create, compose, invent, predict, design, or propose. With technology, students might create a public service announcement video, compose and perform a musical composition, change a current song or poem with new rhythms or words, design a logo or book cover, collaborate on a discussion board or wiki, write and record a podcast, or propose an invention. At this level, what students produce generally has significance to them. In other words, this level includes on the redefinition level of SAMR model.

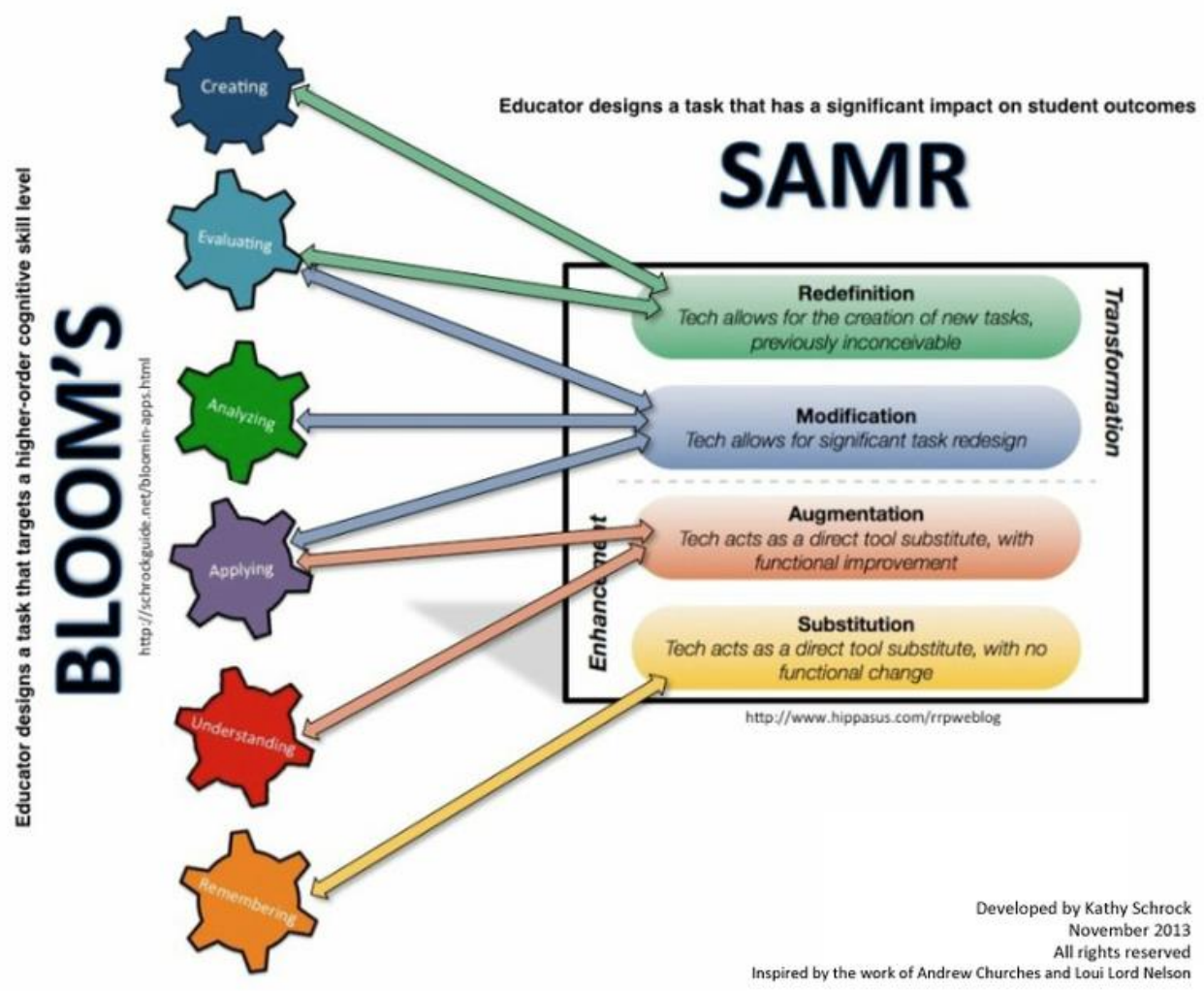

Figure 1 SAMR Model

\section{METHOD}

In conducting the study, the researcher used qualitative research to answer the research question which is related to the English classroom instruction. Qualitative research is concerned with qualitative phenomenon, i.e., phenomena relating to or involving quality or kind.This method is appropriate to identify and describe a problem in which the researcher directly observes and records notes on people in a natural setting for an extended period. (W. Lawrence Neuman 2014: 51. )

The subject of this research were two English teachers. The data were transformed into descriptive text and interviewed transcripts. The data analysis used reduction data, the data display, and conclusion drawing or verification. The data validation used triangulation of technique of collecting data and triangulation of source of data. The researchers give some interview and question about what, why and how the technology and media use in online learning during pandemic. 


\section{RESULTS AND DISCUSSION}

The researcher analysed the technology categories which are used by the teacher and classify the teachers technology integration that used in teaching SMA N 1 SENTOLO.; The researcher collected the data by interviewing and observing the English teachers. It was collected on Thursday 22nd of November.

Table 1 Technology and Media Categories

\begin{tabular}{ll}
\hline \multicolumn{1}{c}{ Technology categories } & \multicolumn{1}{c}{ Media Technology used } \\
\hline Word processing & MS word,adobe reader \\
Multimedia & MS powerpoint, windows media player \\
\hline
\end{tabular}

The tables show how and what the teacher used technology categories in learning activity.

After analyzing the technology categories which had been used by the teacher, the researcher related those technologies into the English learning activity. The researcher tried to know the teacher ${ }^{\text {ee }}$ s technology integration level based on SAMR model the Researcher also conducted this study by interviewing the teacher in order to know another technology category integrated by the teacher.

Table 2 Technology and Media Categories based on SAMR

\begin{tabular}{ll}
\hline \multicolumn{1}{c}{ Technology category } & \multicolumn{1}{c}{ Technology used } \\
\hline Word processing application & MS Word,Adobe acrobat reader \\
Spread sheet software & MS EXCEL \\
Multimedia & MS Power Point \\
Web resource & Movies,Picture \\
\hline
\end{tabular}

\section{Discussion}

The result of the research was known concretely after doing an analysis of the data. By using this analysis, the researcher was able to know the technology categories integrated by the teacher and the teachers technology integration level in the English class instruction at SMA N 1 SENTOLO

The teacher integrates three technology categories in the English class which are word processing application, spread sheet software and multimedia category. While, two technology categories, such as organizing category and web resources are used by the teacher out of the English class for preparing materials.

In this study, the teacher is on the augmentation level when the teacher teach writing skill, in addition the teacher presents the materials is also on the augmentation level. In other words, the teacher had passed the substitution level, because the teacher uses technology as direct tools substitute with functional improvement. Moreover, based on the limitation of the study, it is only focusing on four English skills, which are listening, reading, speaking, and writing. Therefore, in this study the teacher is identified on the Augmentation in the teaching writing, which the teacher uses Microsoft Word as a word processing with additional functions, like spell check, cut and paste the document. 


\section{CONCLUSION}

From the analysis in the chapter four regarding to the technology integration level, there are two points the first is about technology category integrated by teacher and the teacher's technology integration level in the English class

1. Technology category integrated by teacher

The teacher integrates some technology categories which are word processing, spreadsheet software, organizing and brainstorming,multimedia, web resources, and communication software. The teacher integrates three technology categories in the English classroom instruction which are word processing application,spread sheet software and multimedia category. While, two technology categories, such as organizing and brainstorming category and web resources are used by the teacher out of the English class. Those technology categories are integrated by the teacher for making students having the same understanding on the materials.

2. Teacher's technology integration level

Considering the technology categories are integrated by the teacher, this study only focuses in teaching four English skills, they are listening, reading, speaking, and writing. By analyzing those activities in the teaching four English skills, the researcher tries to know the teacher's technology integration level in the teacher learning process. Based on SAMR model the teacher is classified on the augmentation level. It means the teacher passed the substitution level, because the teacher is on the augmentation level, which integrates technology as a direct tool substitute, with functional improvement. Therefore, the teacher is classified on the augmentation level in teaching writing in which the teacher integrates word processing with additional functions like spell check, cut/paste the documents and grammarly.

\section{ACKNOWLEDGMENT}

The highest gratitude would be addressed to University of PGRI Yogyakarta and My family,my friend.

\section{REFERENCE}

Andrew, Elizabeth H. (2016). Doctoral Dissertation: "Teacher Pedagogy to Develop Student Writing through the Integration of text-To-Speech Technology". Australia: Flinders University.

Beisel, Carolyn Anne. (2017). Doctoral Dissertation: "New or Novice Teacher Integration of Mobile Learning Instruction". Walden: Walden University.

Barnaba H Yudha, \& Rahmawan D Andi. (2019). English writing errors of non-English Departement Students. Journal of English Taching and Learning Issues Volume 2 2019 page 131-142,. DOI:10.21043/jetli.v2i2.5740

Cennamo, Katherine S., John D. Ross, Peggy A. (2010). Ertmer.Technology Integration for Meaningful Classroom Use a Standards-Based Approach. USA: Cengage Learning.

Chell, Geraldine, Sean Dowling, (2018). "Substitution to Redefinition: TheChallenges ofUsing Technology” (http://www.researchgate.net, accessed on May 03, 2018) 
Chin Lin, Grace Hui- Paul Shih-chieh Chien. (2018). An Introduction to English Teaching: A Textbook for English Educators (http://ebooks.lib.ntu.edu.tw, accessed on September 30, 2018)

District 220 SAMR Activity Scale for Technology Opportunities, (www.bsd220tech.blogspot.sg, accessed on April 29, 2018)

Dokstader, Joelene. (1999). "Teachers of the 21 st century know the what, why, and how of technology integration" T.H.E Journal. Vol. 26 Issue 6. 73-76.

Eady, Michelle J. - Lori Lockyer. "Tools for Learning: Technology and Teaching Strategies". Paper presented at learning to teach in the Primary School Queensland University of Technology, Australia.

Hamilton, Boni. (2015). Integrating Technology in the Classroom Tools to Meet the Needs of Every Student.USA: ISTE.

Hennesy. (2005). technology integration offers benefits for English language teaching and learning (ELTL).

Hockly, Nicky. (2013). "Technology for the Language Teacher: Mobile Learning" ELT Journal. Vol.67. 80-84.

Kamijo, Marta Mercedes. (2017). "Evaluating Mobile Learning Activities" Tesol Connections. Argentina.

Kihoza, Patrick, Irina Zlotnikova, Joseph Bada, Khamisi Kalegele. (2016). "Classroom ICT integration in Tanzania: Opportunities and challenges from the perspective of TPACK and SAMR models". International Journal of Education and Development using Information and Communication Technology (IJEDICT). Vol. 12, Issue 1. 107-128.

Lobo, Alejandra Glangiulio, Rocio Lara Jimenez. (2018). "Evaluating Basic Grammar Projects, Using the SAMR Model”. Letras 61, 2017. (http://dx.doi.org/10.15359/rl.1-61.5, accesses on June 13, 2018)

Neuman, W. Lawrence. (2014). Social Research Methods: Qualitative and Quantitative Approaches. United States of America : Pearson New International Edition.

Park, Joseph J. (2014). “ The Use of Profesional Learning Networks and Technology Integration". Papper presented for requirement for 61-683.

Philips, Michael. (2015). “Digital Technology Integration.” In hendersen, M Romeo, G. (ED). Teaching and NDigital Technologies: Big Issues and Critical Questions. Melbourne: Cambridge University Press.

Floris, F. D., \& Renandya, W. A. (2017). Transforming the teaching of listening and reading using the SAMR Model. Modern English teacher, 26(4), 41-44.

Harendita, M. (2013). Why resist? A closer look at Indonesian teachers' resistance to ICT. International Journal of Indonesian Studies, 1,42-57.

Jude, L. T., Kajura, M. A., \& Birevu, M. P. (2014). Adoption of the SAMR model to asses ICT pedagogical adoption: A case of Makerere University. International Journal of e-Education, e- Business, e-Management and e-Learning, 4(2), 106.

Kirkland AB. (2014). Models for Technology Integration in the Learning Commons.School Libraries in Canada 32 (1) 14-18.

Liu, P.-H. E., \& Tsai, M.-K. (2013). Using augmented-reality-based mobile learning material in EFL English composition: An exploratory case study. British Journal of Educational Technology, 44(1), E1-E4. doi:10.1111/j.1467-8535.2012.01302.x

Machmud, K. (2011). The integration of technology in a decentralized curriculum setting: The Case of English as a Foreign Language (EFL) Instruction in Gorontalo, Indonesia. United State of America: Ohio University 
Puentedura, R. R. (2015). SAMR: A brief introduction. Retrieved October 2, 2019.

Romrell, Danae, Lisa C. Kidder, Emma Wood. (2013). "The SAMR Modelas a Framework for Evaluating m-Learning”. Evaluating m-Learning. United State of America: Idaho State University.

Sandanayake, T. C. (2019). Promoting open educational resources-basedblended learning: Revista de universidad y sociedad delconocimiento. International Journal of Educational Technology inHigher Education, 16(1), 116.doi:http://dx.doi.org/10.1186/s41239-019-0133-6

Hennesy. (2005). technology integration offers benefits for English language teaching and learning (ELTL). 